\title{
Influence of milk treatment and ripening conditions on quality of Raclette cheese
}

\author{
Thorid Klantschitsch ${ }^{\mathrm{a}}$, Hans-Peter BaCHMAnN ${ }^{\mathrm{b} *}$, Zdenko PuHAN $^{\mathrm{a}}$ \\ ${ }^{a}$ Laboratory of Dairy Science, Swiss Federal Institute of Technology, Zurich, Switzerland \\ b Swiss Federal Dairy Research Station, Liebefeld, Berne, Switzerland
}

\begin{abstract}
The influence of ripening temperature $\left(11,14,17,20^{\circ} \mathrm{C}\right)$ and ripening time $(60$, 90 days) on sensory properties and melting quality of Raclette cheeses made from raw milk, pasteurised milk and microfiltered milk has been investigated using the 'special cubic model' experimental design. With increased ripening temperature substantial acceleration of ripening was achieved. The higher ripening temperature led to higher counts of propionibacteria in raw milk cheeses, and, independent of the milk treatment, to higher concentration of free short chain acids, accelerated proteolysis, higher aroma intensity, decrease in water content and higher firmness. Raw milk Raclette should be ripened at $\leq 11^{\circ} \mathrm{C}$ for 90 days, whereas pasteurised milk Raclette can be ripened at $\leq 14{ }^{\circ} \mathrm{C}$ for 90 days and microfiltered milk Raclette at $17^{\circ} \mathrm{C}$ for 60 days in order to achieve comparable sensory properties and melting quality.
\end{abstract}

Raclette cheese / milk treatment / pasteurization / microfiltration / accelerated ripening / melting quality

\section{INTRODUCTION}

Raclette cheese is a Mountain cheese of Swiss origin; in the past it has been manufactured exclusively from raw milk in the Alps in Wallis during the summer months. As the popularity and therefore the demand for this cheese variety increased because of catering trade, Raclette cheese is being now produced from raw and pasteurised milk during the whole year in lowland regions. At present Raclette is the most important semi-hard cheese in Switzerland and belongs, besides Emmentaler and Gruyère, to the most often manufactured cheese varieties with a volume of $11600 t$ per year. Raclette cheese is consumed in a melted form as "racler" (means to scrape, to shed) and has to possess specific properties such as no fat separation as oiling off, proper break

\footnotetext{
* Correspondence and reprints. hans-peter.bachmann@fam.admin.ch
} 
off of the melted body and the perception of toughness, but not rubberiness like chewing gum, in the mouth $[12,13]$. The commercial Raclette cheeses from raw or pasteurised milk show significant sensory differences. In general, cheeses made from pasteurised milk are considered milder whereas raw milk cheeses develop a more intense flavour. The raw milk microorganisms appear to be the primary factor for the differences between raw milk Raclette and Raclette made from pasteurised milk [15].

A technology based on crossflow microfiltration, a pressure-driven filtration using a membrane pore size of $1.4 \mu \mathrm{m}$, has been introduced by Holm et al. [8] and Piot et al. [31] with the aim to remove very efficiently bacteria and spores from milk. On average, the content of bacteria in the milk is reduced to few hundred counts / $\mathrm{mL}$, independent of the initial level of the bacterial population [36].

The microfiltration process for debacteriazation, marketed as the "Bactocatch" process $[26,29,37]$ has proved to be suitable for manufacturing Grevé and Herrgårds cheese [25], Comté-type cheese [7], Swisstype cheese $[6,9,10]$ and Cheddar cheese $[28,33]$. These investigations showed that the indigenous flora of milk can be significantly reduced by microfiltration, however, with the result that the overall aroma intensity of the cheeses compared to raw milk cheeses is less pronounced.

Raw milk Raclette cheese is usually ripened at $11{ }^{\circ} \mathrm{C}$ for 90 days. At higher ripening temperatures, propionibacteria are involved in undesirable secondary fermentation. Bouton et al. [7] found that Comté cheese made from microfiltered milk had a lower concentration of propionic acid than cheese made with raw milk. The reduction of propionibacteria by microfiltration allows the acceleration of ripening by increasing the ripening temperature without the risk of propionic acid fermentation. To our knowledge, no investigations have been recorded in the literature characterising ripening of
Raclette produced from MF milk at elevated temperatures.

The purpose of this study was to investigate the influence of ripening temperature at four levels $\left(11,14,17,20^{\circ} \mathrm{C}\right)$ and ripening time at two levels (60, 90 days) on sensory properties and melting quality of Raclette cheese made from raw milk, pasteurised milk and microfiltered milk using a 'special cubic model experimental design'.

\section{MATERIALS AND METHODS}

\subsection{Cheese manufacture}

Raw milk was separated into cream and skim milk at $30^{\circ} \mathrm{C}$. A third of the skim milk was microfiltered at $40{ }^{\circ} \mathrm{C}$. A microfiltration unit from Tetra Alcross M (MFS-7 pilot plant, Tetra Pak Filtration Systems, Lund, Denmark) with Sterilox membrane (pore size of $1.4 \mu \mathrm{m}$, surface area of $1.4 \mathrm{~m}^{2}$, flux of $300 \mathrm{~L} \cdot \mathrm{h}^{-1} \cdot \mathrm{m}^{-2}$, concentration factor $20: 1$ ) was used. Cream and MF retentate were separately high temperature treated (HTT) at $121{ }^{\circ} \mathrm{C}$ for $4 \mathrm{~s}$ and remixed with MF skim milk at $40{ }^{\circ} \mathrm{C}$ in a sterilised cheese vat to standardise the fat content $(3.5 \%)$. Nonmicrofiltered raw and pasteurised skim milk was mixed with HTT cream in the same way. The pasteurisation of skim milk was carried out in the cheese vat (Fig. 1).

Raclette cheeses were produced in the pilot plant of the FAM (Swiss Federal Dairy Research Institute, Liebefeld, Bern, Switzerland) according to the following manufacturing protocol: $70 \mathrm{~L}$ cheesemilk was placed in a sterilised steel cheese vat, inoculated with $2 \mathrm{~g}$ mesophilic starter culture (Lactococcus lactis subsp. lactis and subsp. cremoris, MA011, Texel, Winkler, Switzerland) and pre-ripened at $28{ }^{\circ} \mathrm{C}$ for $45 \mathrm{~min}$. The milk was than adjusted to $32{ }^{\circ} \mathrm{C}$ and 12 mL Rennet (Standard Labextrakt, Winkler, Switzerland), diluted in $1 \mathrm{~L}$ water, added. After $30 \mathrm{~min}$, when the coagulum reached the desired consistency, it was cut to grains of 10-20 mm diameter; $30 \mathrm{~L}$ water 


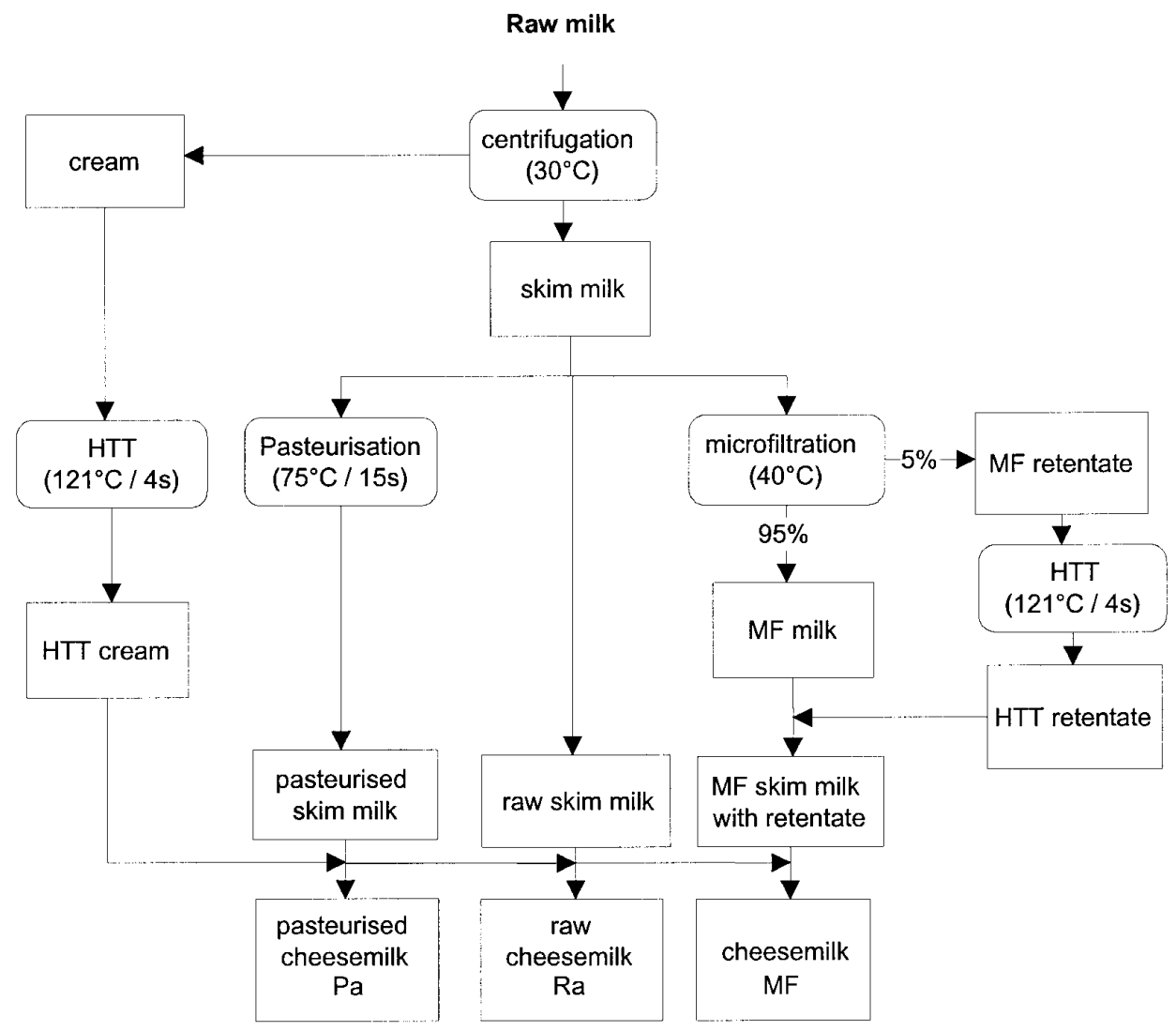

Figure 1. Preparation of milk for cheesemaking.

of $30{ }^{\circ} \mathrm{C}$ was added, the mixture heated to $38{ }^{\circ} \mathrm{C}$ in $15 \mathrm{~min}$ and stirred for additional $15 \mathrm{~min}$ at $38{ }^{\circ} \mathrm{C}$. A part of the whey was drained off and the curd was pressed in a mould at 6 bar for 15 min and subsequently at 8 bar for $30 \mathrm{~min}$. The cheese remained in the mould overnight. The temperature decreased from $35{ }^{\circ} \mathrm{C}$ to $25^{\circ} \mathrm{C}$ and the $\mathrm{pH}$ was in 5.2-5.1 range. Afterwards, the cheeses were placed in a saturated $\mathrm{NaCl}$ brine of $11-12{ }^{\circ} \mathrm{C}$ for $24 \mathrm{~h}$. Ripening conditions were $11,14,17,20^{\circ} \mathrm{C}$ or 60 and 90 days at $95 \%$ relative humidity.

Cheeses were made according to the experimental design from $100 \%$ raw, past. or MF milk, from 50/50 combinations of each, or from 1/3 1/3 1/3 mixture of all three milk types. All cheeses were manufactured in duplicate for each of the ripening conditions $\left(11,14,17,20^{\circ} \mathrm{C}\right)$ and analysed after 60 and 90 days of ripening for microbial flora, glycolysis, lipolysis and proteolysis, sensory properties and melting quality.

\subsection{Microbiological analysis}

The cheesemilk, as well as the cheeses at the end of maturation, were examined for their microflora. Enterobacteriaceae were determined on VRBG agar $\left(1\right.$ day, $\left.37{ }^{\circ} \mathrm{C}\right)$ [1]. Enterococci were analysed on kanamycin aesculin azide agar medium ( 2 days, $37^{\circ} \mathrm{C}$ ) [30]. Propionibacteria were analysed on lactate agar $\left(10\right.$ days, $\left.30^{\circ} \mathrm{C}\right)$ [17]. 
Psychrotrophs were analysed on standard methods agar incl. $1.0 \mathrm{~g}$ skim-med milk powder per litre (10 days, $\left.6.5^{\circ} \mathrm{C}\right)$ according to [22]. Salt tolerant bacteria were analysed on mannite- $\mathrm{NaCl}$ agar $\left(2\right.$ days, $\left.37^{\circ} \mathrm{C}\right)$ [36]. Facultatively heterofermentative Lactobacilli were anaerobically analysed on agar with mannite (3 days, $\left.38^{\circ} \mathrm{C}\right)$ [24].

\subsection{Chemical analysis}

Total nitrogen (TN), pH 4.6 soluble nitrogen (SN4.6) and non protein nitrogen (NPN) as the $12 \%$ TCA soluble nitrogen, were determined by the Kjeldahl method according to [20] with a Büchi B-435 digestion unit and a Büchi B-339 distillation unit (Flawil, Switzerland). The SN4.6 and NPN fractions were prepared according to the method of Collomb et al. [8] and the results expressed in \% total nitrogen. After isolation from cheese by steam distillation, free short chain acids (acetic and propionic) were determined by gas chromatography using a flame ionisation detector [5]. The water content was analysed gravimetrically [19], the fat content according to Gerber-van-Gulik method [23] and $\mathrm{NaCl}$ was calculated from Chloride determined potentiometrically [21].

\subsection{Sensory analysis and melting quality}

After 60 and 90 days of ripening, the sensory characteristics of the model cheeses were judged by a group of six cheese experts of the FAM according to a standard protocol. The experts applied the standard grading method concerning flavour (score: worst 1 to best 6), texture (score: worst 1 to best 6 ), preference (score: lowest 1 to highest 6 ) and intensity of aroma (score: lowest 2 to highest 8). The melting qualities of the model Raclette were judged by a panel of five cheese experts of the FAM according to a protocol regarding separation of fat (score slight 1 to strong 5), viscosity (liquid 1 to viscous 7), consistency (short 1 to long 7) and firmness (soft 1 to solid 7). In addition, the softening and dropping points were measured with an automatic Mettler-Thermosystem 800 with the Dropping point cell FP 83 [16].

\subsection{Simplex lattice experimental design}

"Mixture designs", such as the simplex lattice experimental design, are suitable for situations where different excipients are mixed to obtain optimal characteristics. To optimise the composition of a three component mixture, the simplex experimental design is a triangle [27].

The experimental design of the study contained three components: raw milk $\left(\mathrm{x}_{1}\right)$, pasteurised milk $\left(\mathrm{x}_{2}\right)$ and microfiltered milk $\left(\mathrm{x}_{3}\right)$ with seven points (variants) constituting a special cubic model design [27]. The distribution of the experimental points in the ternary diagram is shown in Figure 2. The design demands a total of 7 cheeses to be produced. Since the pilot plant equipment consisted of eight vats, the variant 7 was manufactured in duplicate. Each day, the eight treatment combinations were allocated to the vats at random.

The reason for the application of the special cubic model design was to differentiate between the chemical and microbiological effects of the milk treatment. The model allows to determine the dependence of an 'optimum point' from milk treatment, ripening temperature and ripening time.

\subsection{Statistical analysis}

The special cubic model design can be expressed as a graph in a triangle form determined by seven points of cheeses made from differently treated milk. Each axis of the graph represents the cheeses of one of the three milk treatments with the mixture composition from 0 to $100 \%$. Based on the seven determined variants (points) the software SYSTAT (Systat for Windows, Version 


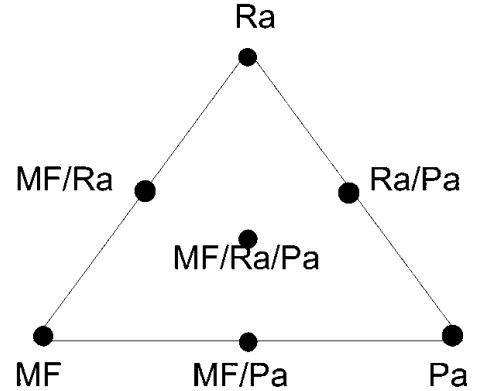

Figure 2. Principle of 'special cubic model design' for cheesemaking from raw milk (Ra), pasteurised milk $(\mathrm{Pa})$, microfiltered milk (MF).

7.0.1, SPSS, Chicago 1997) calculated the corresponding curves in the simplex lattice diagram. The size (diameter) of each of the seven points represents the mean value.

\section{RESULTS AND DISCUSSION}

\subsection{Cheese composition}

The gross compositions of the cheeses after 60 and 90 days of ripening are summarised in Table I. No significant difference was found between the cheeses of different milk treatments ripened at the same temperature. To evaluate the overall influence of ripening temperature and time the average of all cheeses is shown. At elevated ripening temperature and longer ripening time the water content decreased as a result of water evaporation. The fat in dry matter of all cheeses ranged between 512 and $519 \mathrm{~g} \cdot \mathrm{kg}^{-1}$, the $\mathrm{NaCl}$ content between 18 and $21 \mathrm{~g} \cdot \mathrm{kg}^{-1}$. Schär et al. [35] found that in Walliser Raclette cheese of good quality the cheeses lost during ripening (stored at $11^{\circ} \mathrm{C}$ ) up to $30 \mathrm{~g}$ water per $\mathrm{kg}$ cheese until the stadium of full maturity at 120 days. This was due to the influence of salt adsorption during brining and the evaporation of water through the rind during maturation. According to Eberhard et al. $[12,13]$ the mean $\mathrm{NaCl}$ content of $21.8 \mathrm{~g} \cdot \mathrm{kg}^{-1}$ indicated cheeses of good melting quality whereas with $\mathrm{NaCl}$ content of $24.2 \mathrm{~g} \cdot \mathrm{kg}^{-1}$ the melting quality was poor.

\subsection{Microbiological analyses}

The standardised cheesemilk for the manufacture of the Raclette cheeses was analysed for its bacterial counts (Tab. II). The pasteurised $(\mathrm{Pa})$ and microfiltered (MF) cheesemilk contained counts of

Table I. Mean chemical composition $\left(\mathrm{g} \cdot \mathrm{kg}^{-1}\right)$ of all Raclette cheeses at different ripening temperatures after 60 and 90 days.

\begin{tabular}{lcccc}
\hline \multirow{2}{*}{ Age [days] } & \multicolumn{3}{c}{ Chemical composition } \\
\cline { 3 - 5 } & Ripening temperature $\left[{ }^{\circ} \mathrm{C}\right]$ & Water content & Fat content & $\mathrm{NaCl}$ \\
\hline 60 & 11 & $416.6 \pm 9.7$ & $301.1 \pm 8.6$ & $18.7 \pm 2.2$ \\
14 & $408.9 \pm 8.9$ & $303.1 \pm 7.4$ & $19.3 \pm 2.2$ \\
17 & $400.5 \pm 8.9$ & $308.1 \pm 6.8$ & $20.1 \pm 2.0$ \\
& 20 & $398.9 \pm 4.8$ & $310.5 \pm 7.0$ & $19.2 \pm 2.2$ \\
& 11 & $410.1 \pm 9.9$ & $306.1 \pm 9.2$ & $19.0 \pm 1.9$ \\
14 & $401.3 \pm 9.8$ & $309.3 \pm 9.1$ & $19.7 \pm 2.3$ \\
17 & $388.2 \pm 6.1$ & $313.8 \pm 7.0$ & $20.4 \pm 1.5$ \\
& 20 & $392.9 \pm 8.3$ & $314.5 \pm 8.4$ & $19.5 \pm 1.7$ \\
& & & &
\end{tabular}

Each value is the mean of 16 replicates \pm standard deviation. 
psychrotrophs and salt tolerant bacteria at a maximum level of $100 \mathrm{cfu} \cdot \mathrm{mL}^{-1}$; enterococci, facultatively heterofermentative lactobacilli (FHL) and propionibacteria were below the detection limit of $10 \mathrm{cfu} \cdot \mathrm{mL}^{-1}$. The raw (Ra) cheesemilk was of good bacterial quality. All mixed cheesemilk ( $\mathrm{Ra}$, $\mathrm{Pa}, \mathrm{MF}$ milk) showed counts according to those in the milk components. These results are in agreement with Demarigny et al. [9] and Beuvier et al. [6] who found absence of, or only low counts of enterococci, FHL and propionibacteria in MF and $\mathrm{Pa}$ cheesemilk.

Changes in the numbers of enterococci, FHL and propionibacteria in the cheeses at four different ripening temperatures after 60 and 90 days of ripening are shown in Figure 3. With respect to the counts of enterococci, FHL and propionibacteria the Raclette cheeses after 60 and 90 days could be divided into two groups: (a) cheeses made from raw milk or with raw milk added and (b) cheeses made from pasteurised and microfiltered milk or their combinations. For cheeses from the 1st group, enterococci counts ranged between $10^{6}$ and $10^{7} \mathrm{cfu} \cdot \mathrm{g}^{-1}$, irrespective of the added amount of raw milk. Cheeses from $\mathrm{Pa}$ and $\mathrm{MF}$ milk contained less than $10^{2} \mathrm{cfu} \cdot \mathrm{g}^{-1}$. In none of the cheeses an additional growth for enterococci at higher ripening temperature or longer ripening time was detected. In a previous, study Walliser Raclette cheese of good quality showed a mean value for enterococci of $1.3 \times 10^{4} \mathrm{cfu} \cdot \mathrm{g}^{-1}$ and $4.3 \times 10^{4} \mathrm{cfu} \cdot \mathrm{g}^{-1}$, resp. [35], after 60 days and 130 days of ripening, whereas the enterococci count for pasteurised Raclette cheese after 120 days of ripening was below the detection limit of $10 \mathrm{cfu} \cdot \mathrm{g}^{-1}$ [17]. In all cheeses made with raw milk, the count of FHL was at a constant level of $10^{8} \mathrm{cfu} \cdot \mathrm{g}^{-1}$ regardless of the ripening temperature or time. FHL concentration of MF cheeses was lower than in $\mathrm{Pa}$ cheeses (below $10^{3} \mathrm{cfu} \cdot \mathrm{g}^{-1}$ and $10^{5} \mathrm{cfu} \cdot \mathrm{g}^{-1}$, resp.). In contrast to counts of enterococci and FHL the propionibacteria counts in cheeses with raw milk increased at ripening temperature above $11^{\circ} \mathrm{C}$ whereas in MF and $\mathrm{Pa}$ cheeses the count remained on the same level. At $17^{\circ} \mathrm{C}$ and $20^{\circ} \mathrm{C}$ of ripening the growth of propionibacteria in raw milk cheeses was significantly enhanced thus increasing the risk of secondary fermentation. Schär et al. [35] found that propionibacteria counts above $10^{6} \mathrm{cfu} \cdot \mathrm{g}^{-1}$ indicated secondary fermentation. In $\mathrm{MF}$ and $\mathrm{Pa}$ cheeses propionibacteria were not detectable after 60 days; after 90 days at $17{ }^{\circ} \mathrm{C}$ and $20{ }^{\circ} \mathrm{C}$, the counts were slightly increased to

Table II. Bacterial populations $\left(\log 10 \mathrm{cfu} \cdot \mathrm{mL}^{-1}\right)$ in raw (Ra), pasteurised (Pa), microfiltered (MF) cheesemilk and its mixtures, mean values \pm standard deviation.

\begin{tabular}{lccccc}
\hline & \multicolumn{5}{c}{ Standardised cheesemilk } \\
\cline { 2 - 6 } & $\begin{array}{c}\text { Entero- } \\
\text { cocci }\end{array}$ & $\begin{array}{c}\text { Fac. het. } \\
\text { lactobacilli }\end{array}$ & $\begin{array}{c}\text { Psychro- } \\
\text { trophs }\end{array}$ & $\begin{array}{c}\text { Propioni- } \\
\text { bacteria }\end{array}$ & $\begin{array}{c}\text { Salt } \\
\text { tolerant bacteria }\end{array}$ \\
\hline Ra milk & $2.0 \pm 0.4$ & $2.2 \pm 0.2$ & $3.0 \pm 0.7$ & $1.1 \pm 0.6$ & $3.8 \pm 0.3$ \\
Pa milk & nd & nd & $1.0 \pm 0.5$ & nd & $1.3 \pm 0.5$ \\
MF milk & nd & nd & $1.0 \pm 0.4$ & nd & $1.2 \pm 0.5$ \\
$\mathrm{Ra} /$ Pa milk & $1.9 \pm 0.2$ & $1.9 \pm 0.1$ & $2.9 \pm 0.4$ & $0.9 \pm 0.2$ & $3.4 \pm 0.1$ \\
$\mathrm{~Pa}$ / MF milk & nd & nd & $1.0 \pm 0.5$ & nd & nd \\
$\mathrm{Ra} / \mathrm{MF}$ milk & $2.1 \pm 0.3$ & $2.0 \pm 0.5$ & $3.1 \pm 0.9$ & $0.9 \pm 0.3$ & $3.4 \pm 0.5$ \\
$\mathrm{Ra} / \mathrm{Pa}$ / MF milk & $1.9 \pm 0.2$ & $1.9 \pm 0.4$ & $2.7 \pm 0.3$ & $1.1 \pm 0.3$ & $3.1 \pm 0.2$ \\
\hline
\end{tabular}

nd: not detectable i.e. below the detection limit of $10 \mathrm{cfu} \cdot \mathrm{mL}^{-1}$. Each value is the mean of four replicates. 

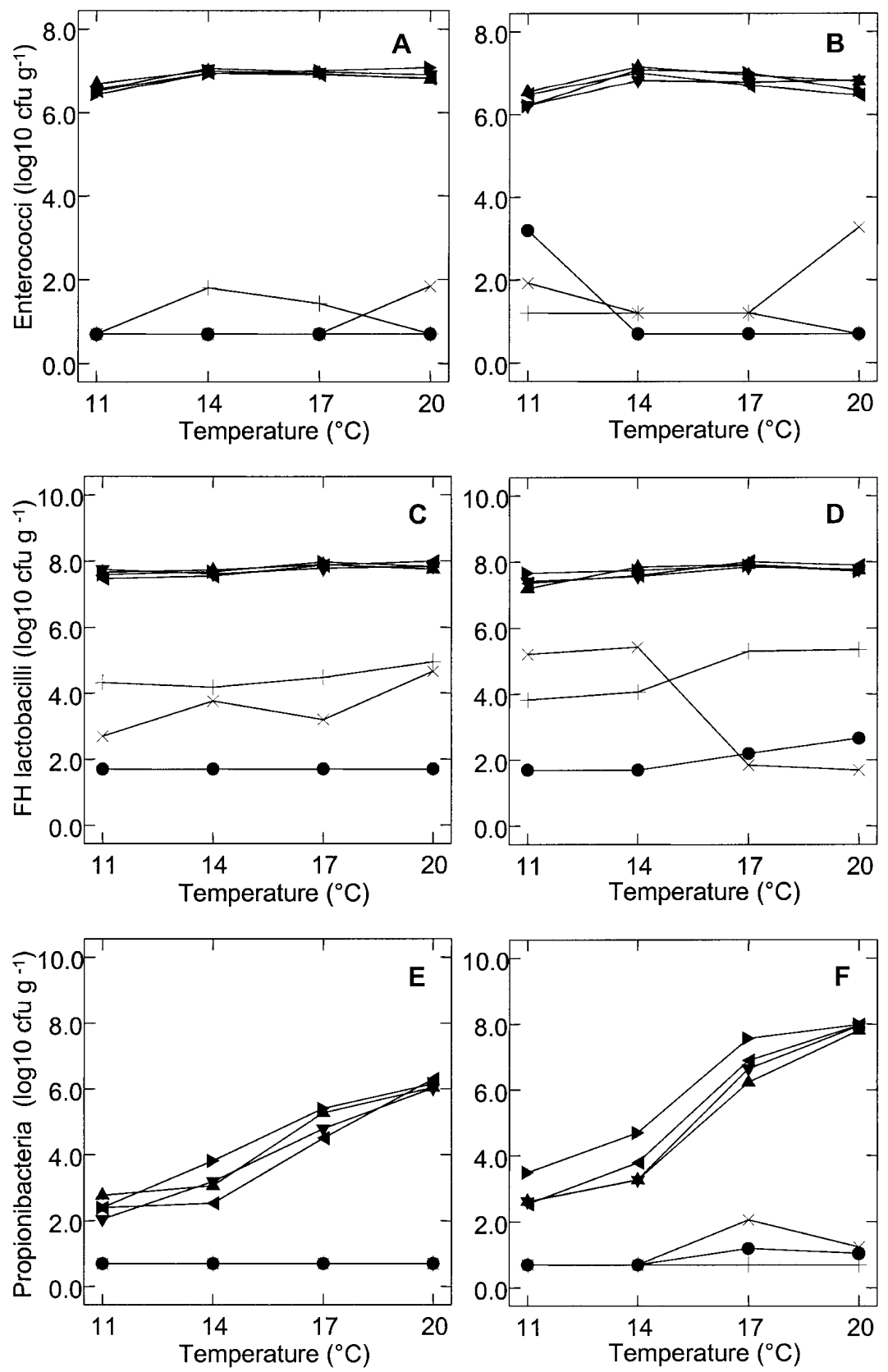

Figure 3. Counts of enterococci after 60 days (A) after 90 days (B), facultatively heterofermentative (FH) lactobacilli after 60 days $(\mathbf{C})$ and after 90 days (D), propionibacteria after 60 days $(\mathbf{E})$ and after 90 days (F) at different ripening temperatures in Raclette cheeses made from raw, pasteurised and microfiltered milk and its mixtures. raw milk $(\mathrm{Ra}),+$ pasteurised milk $(\mathrm{Pa}), \mathbf{m}$ microfiltered milk (MF), $4 \mathrm{Ra} / \mathrm{Pa}(50: 50 \%), \Delta \mathrm{Ra} / \mathrm{MF}$ (50:50\%), $\boldsymbol{\nabla} \mathrm{Ra} / \mathrm{Pa} / \mathrm{MF}$ (33:33:33\%), $\times \mathrm{Pa} / \mathrm{MF}(50: 50 \%)$. Means of two replicates. 
$100 \mathrm{cfu} \cdot \mathrm{g}^{-1}$. These results are opposite to those of Demarigny et al. [9] and Beuvier et al. [6] who found that microfiltration and pasteurisation only delayed the growth of enterococci, FHL and propionibacteria in cheeses. In their studies, these three bacterial populations in MF and $\mathrm{Pa}$ cheeses after 6 weeks were 10 to 100 fold lower than in $\mathrm{Ra}$ cheeses. They concluded that the presence of these microorganisms in $\mathrm{MF}$ and $\mathrm{Pa}$ cheeses may have been the result of contamination during cheese manufacture.

\subsection{Free short chain acids}

Again, the cheeses could be divided into two groups: cheeses made from raw milk or with raw milk added and cheeses made from pasteurised and microfiltered milk and their combinations. The concentration of FSCA in cheeses were higher when the indigenous raw milk flora was present. The concentrations of acetic and propionic acids are summarised in Figure 4. The amount of acetic acid was highly affected by elevated ripening temperatures: after 60 days the acetic acid may have originated mainly from the fermentation of citric acid and after 90 days at $17{ }^{\circ} \mathrm{C}$ and $20{ }^{\circ} \mathrm{C}$ additionally from the fermentation of lactic acid by propionibacteria. This was confirmed by the increased amount of propionic acid in the same period. MF and $\mathrm{Pa}$ cheeses showed no secondary fermentation. Similarly, Gallmann [14] found significant differences regarding acetic and propionic acids between Raclette cheeses made from raw and pasteurised milk after 120 days of ripening as a consequence of indigenous bacterial count.

\subsection{Proteolysis}

The protein and peptide breakdown in all cheeses was highly affected by ripening temperature and time (Fig. 5). After 60 days MF cheeses showed the lowest SN4.6 fraction as indication for the proteolysis "into the width" (SN4.6/TN) whereas the proteolysis "into the depth" (NPN/TN) was almost independent of milk treatment. After 90 days the differences between cheeses with raw milk and MF/Pa cheeses increased with higher ripening temperature. The enhanced proteolysis at elevated temperatures after 90 days can be explained by the fact that secondary fermentation has occurred in cheeses with raw milk as a consequence of high concentrations of propionibacteria. The acceleration of proteolysis at higher ripening temperatures is a well known phenomenon [2, 4, 16, 32]. Temperature adjustments during ripening of Cheddar cheese resulted in manipulation of specific proteolytic activities [2, 4]. The proteolytic activities reflected by breakdown products soluble in $12 \%$ TCA (NPN) were enhanced at higher temperatures, due to the increased activity of proteolytic enzymes. This observation is in good agreement with our results.

\subsection{Sensory evaluation}

Sensory characteristics of cheeses were analysed after 60 and 90 days. The results for attributes 'preference' and 'intensity of aroma' are shown in detail in Figures 6 and 7. Each axis of the graph represents the cheeses of one of the three milk treatments with the mixture composition from 0 to $100 \%$ at defined ripening temperature and time.

With respect to 'preference', Raclette cheeses could again be divided in the same two groups as before, i.e. those made from or with raw milk and those made using pasteurised and microfiltered milk (Fig. 6). The 'preference' attribute was affected more by the elevated ripening temperature than by the ripening time. For all cheeses the scores of 'preference' decreased with elevated temperature and enhanced proportion of raw milk. After 60 days the Pa cheeses ripened at $11^{\circ} \mathrm{C}$ and $14^{\circ} \mathrm{C}$ were scored higher than $\mathrm{MF}$ cheeses. After 90 days MF and $\mathrm{Pa}$ cheeses were judged in the same range. The 

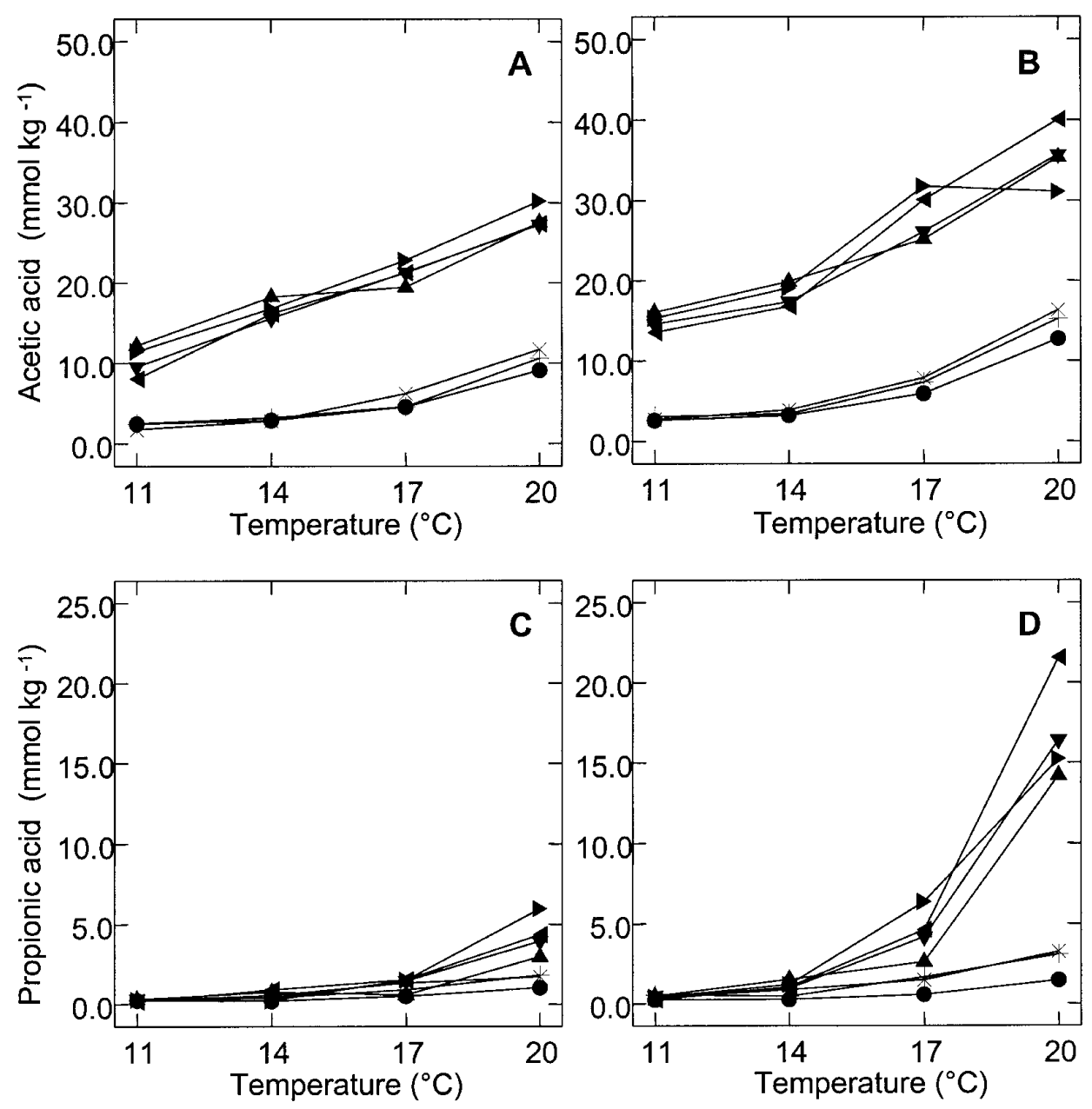

Figure 4. Concentration of acetic acid after 60 days (A) after 90 days (B), propionic acid after 60 days (C) and after 90 days (D) at different ripening temperatures in Raclette cheeses made from raw, pasteurised and microfiltered milk and its mixtures. raw milk (Ra), + pasteurised milk (Pa), $>$ microfiltered milk (MF), $\boldsymbol{\sim} \mathrm{Ra} / \mathrm{Pa}(50: 50 \%), \boldsymbol{\Delta} \mathrm{Ra} / \mathrm{MF}(50: 50 \%), \boldsymbol{\nabla} \mathrm{Ra} / \mathrm{Pa} / \mathrm{MF}(33: 33: 33 \%), \times \mathrm{Pa} / \mathrm{MF}$ (50:50\%). Means of two replicates.

graph curves connecting points of equal values were moving at elevated ripening temperature to an obvious distinction between cheeses made with raw milk and cheeses from MF and Pa milk. Cheeses with scores below 4.0 were considered as defective because of off-flavours and eye formation. Cheeses made with raw milk and at 17 and $20{ }^{\circ} \mathrm{C}$ ripening temperatures for 90 days exhibited off-flavour as a consequence of secondary fermentation. These cheeses showed an off-flavour already after 60 days, however, without detectable signs of propionic acid fermentation.

It can be concluded that the maximum temperature at which Raclette cheeses can be ripened without significant decrease 
in the attribute 'preference' is about $14{ }^{\circ} \mathrm{C}$ (60 days) or $11{ }^{\circ} \mathrm{C}$ (90 days) for cheeses from or with raw milk and $17{ }^{\circ} \mathrm{C}$ (60 and 90 days) for $\mathrm{MF}$ and $\mathrm{Pa}$ cheeses.

The low 'preference' scores at elevated temperature, especially for cheeses made with raw milk, were mainly due to the 'intensity of aroma' being atypical for
Raclette cheese (Fig. 7). Cheeses with scores for 'intensity of aroma' of 5 were in the range of normal maturity and, above 5 , on the limit of being over mature. At elevated ripening temperatures the graph curves indicated higher scores of 'intensity of aroma'. The 'intensity of aroma' of MF cheeses was scored to be lower at 11,14 and $17^{\circ} \mathrm{C}$ after
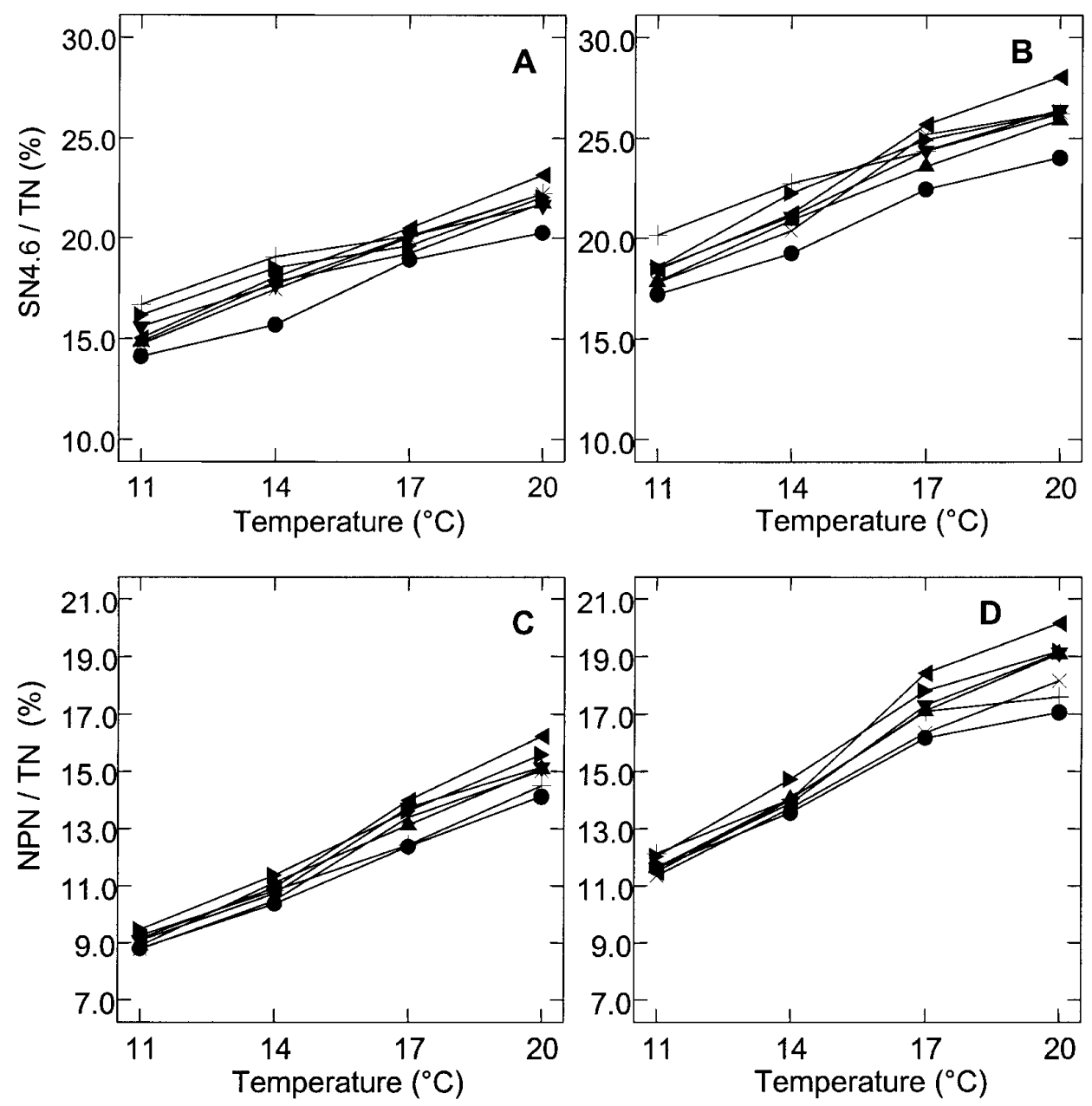

Figure 5. Development of soluble nitrogen at pH 4.6 (SN4.6 in \% of total nitrogen (TN)) after 60 days (A) after 90 days (B), non protein nitrogen (NPN in \% of total nitrogen (TN)) after 60 days (C) and after 90 days (D) at different ripening temperatures in Raclette cheeses made from raw, pasteurised and microfiltered milk and its mixtures. raw milk $(\mathrm{Ra}),+$ pasteurised milk $(\mathrm{Pa}), \boldsymbol{O}$ microfiltered milk (MF), $\varangle \mathrm{Ra} / \mathrm{Pa}(50: 50 \%), \boldsymbol{\Delta} \mathrm{Ra} / \mathrm{MF}(50: 50 \%), \boldsymbol{\nabla a} / \mathrm{Pa} / \mathrm{MF}$ (33:33:33\%), $\times \mathrm{Pa} / \mathrm{MF}$ (50:50\%). Means of two replicates. 

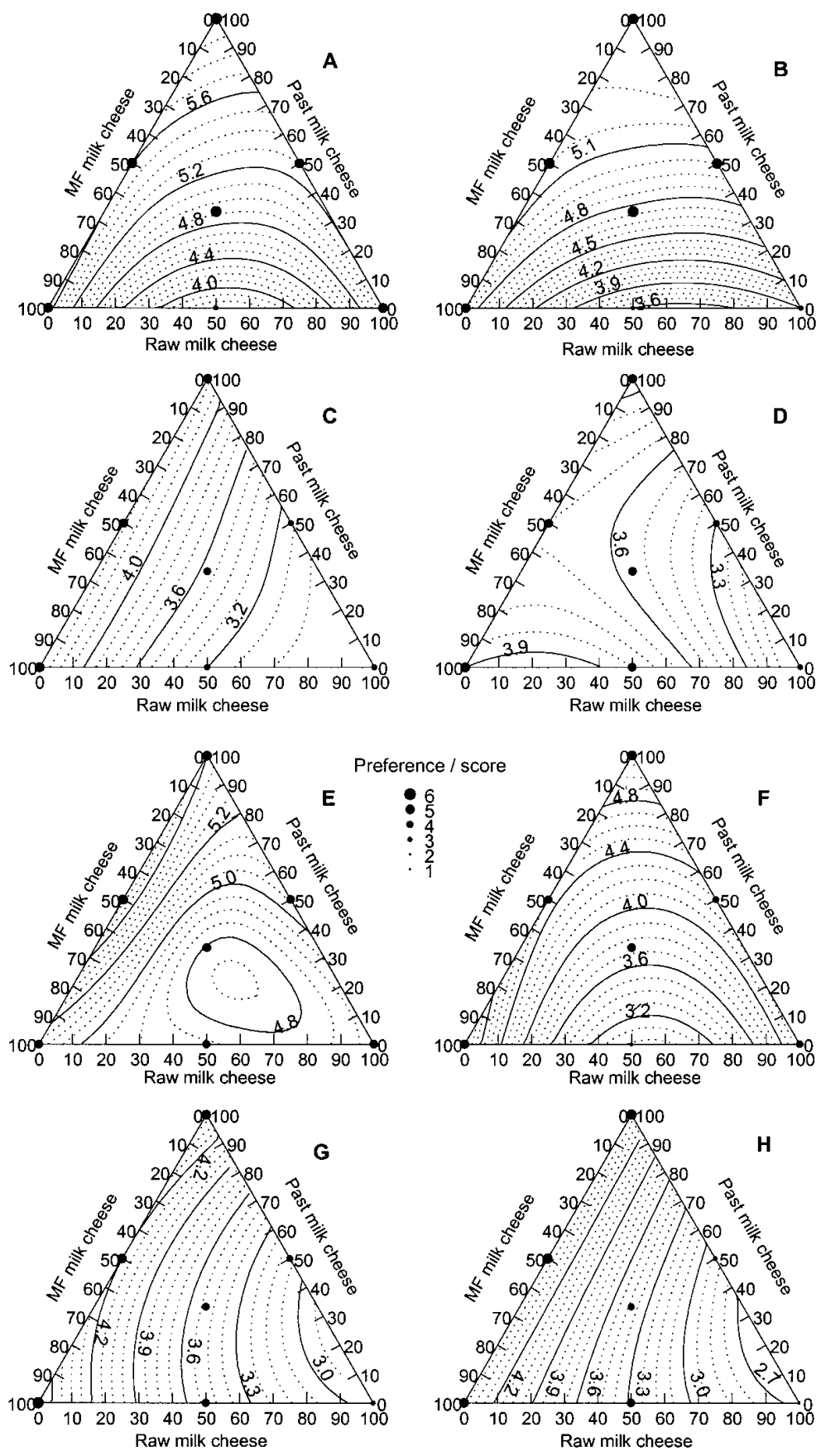

Figure 6. Sensory 'Preference' attribute of Raclette cheese from microfiltered, pasteurised and raw milk ripened for 60 days at $11^{\circ} \mathrm{C}(\mathbf{A})$, at $14{ }^{\circ} \mathrm{C}(\mathbf{B})$, at $17{ }^{\circ} \mathrm{C}(\mathbf{C})$, at $20^{\circ} \mathrm{C}(\mathbf{D})$ and for 90 days at $11^{\circ} \mathrm{C}(\mathbf{E})$, at $14{ }^{\circ} \mathrm{C}(\mathbf{F})$, at $17{ }^{\circ} \mathrm{C}(\mathbf{G})$, at $20^{\circ} \mathrm{C}(\mathbf{H})$. Means of two replicates. 

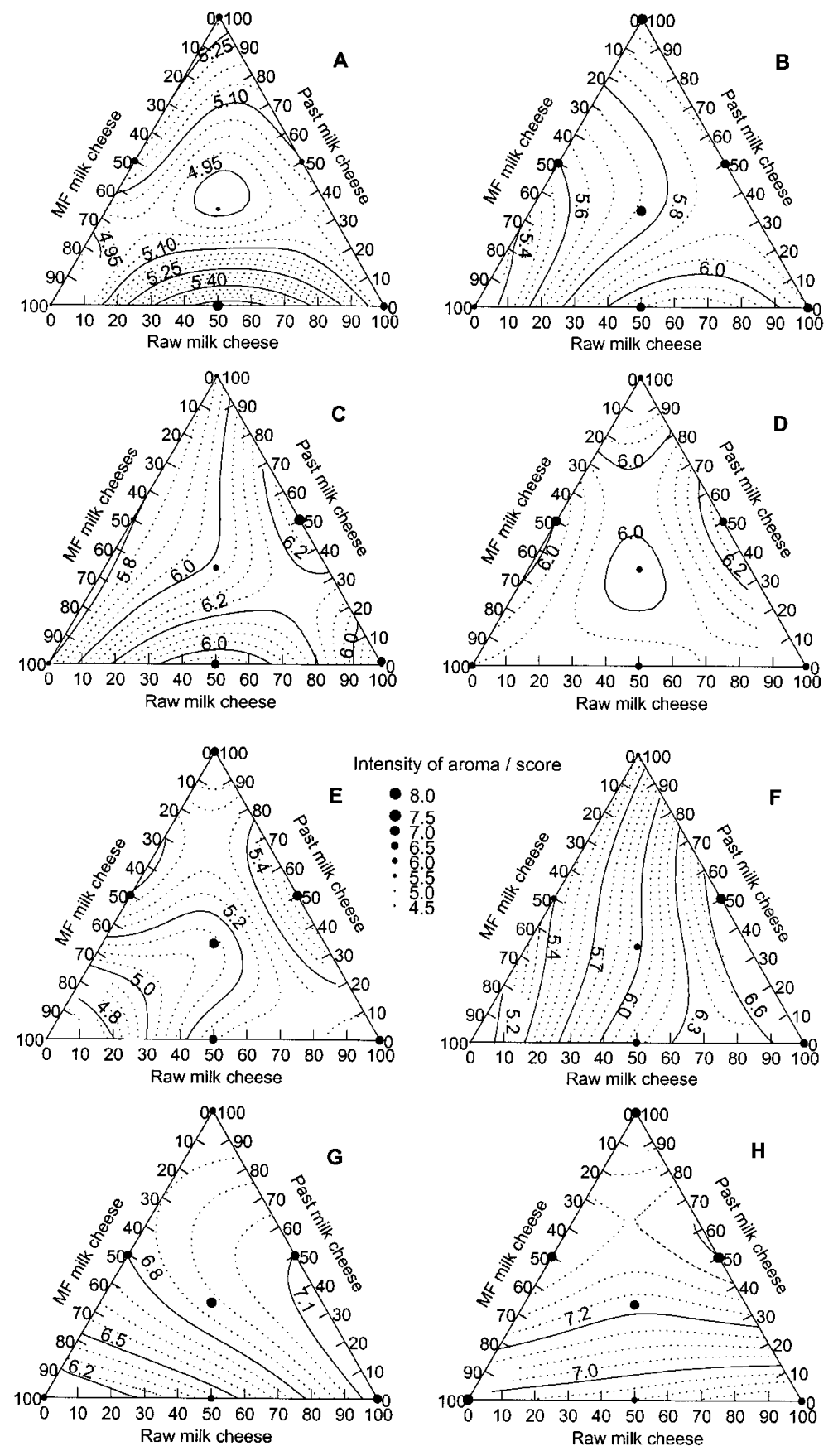

Figure 7. Sensory 'Intensity of aroma' attribute of Raclette cheese from microfiltered, pasteurised and raw milk ripened for 60 days at $11^{\circ} \mathrm{C}(\mathbf{A})$, at $14^{\circ} \mathrm{C}(\mathbf{B})$, at $17^{\circ} \mathrm{C}(\mathbf{C})$, at $20^{\circ} \mathrm{C}(\mathbf{D})$ and for 90 days at $11^{\circ} \mathrm{C}(\mathbf{E})$, at $14{ }^{\circ} \mathrm{C}(\mathbf{F})$, at $17^{\circ} \mathrm{C}(\mathbf{G})$, at $20^{\circ} \mathrm{C}(\mathbf{H})$. Means of two replicates. 
60 and 90 days, i.e. MF cheeses were less mature than cheeses made with raw and $\mathrm{Pa}$ milk. But at $20^{\circ} \mathrm{C}, \mathrm{MF}$ cheeses reached almost the same level of maturity as raw milk and Pa cheeses.

The ripening study showed that at higher ripening temperatures the rate of flavour development was accelerated. The same observation was made by Aston et al. [2-4] with Cheddar cheese, however using only pasteurised milk.

\subsection{Melting quality}

Raclette cheese is mainly consumed in a melted form. The melting properties of the cheeses were characterised by sensory attributes including 'fat separation', 'viscosity', 'consistency' and 'firmness' of the melted cheeses and by 'softening and dropping point' using an automatic dropping point measuring instrument.

The fat separation such as oiling off was determined visually. Figures $8 \mathrm{~A}, 8 \mathrm{~B}$ show the average results for Raclette cheeses of different milk treatment and different ripening temperature after 60 and 90 days. Cheeses without fat separation are denoted by the value of 1 . With longer ripening time the fat separation increased, especially in cheeses made with raw milk. It is known, that in raw milk Raclette cheese fat separation occurs more often than in cheese made from pasteurised milk [13].

Viscosity and consistency were tested using a fork; the viscosity by stirring the melted cheese in the pan and the consistency by lifting the Raclette cheese and assessing the break off of the molten mass. The viscosity of all cheeses decreased, i.e. after melting the cheeses were less viscous with longer ripening time (Figs. 8C, 8D). However, when taking the average for all ripening temperatures the viscosity of raw milk, MF and Pa cheeses after 60 and 90 days was comparable. Generally with longer ripening time the consistency of all cheeses was judged to be 'shorter' (Figs. 8E and $8 \mathrm{~F}$ ). After 60 days the average difference between raw milk, MF and Pa cheeses was small. After 90 days the consistency of the melted cheeses with raw milk was judged to be "longer" than the consistency of MF and Pa milk cheeses.

Eberhard et al. [12, 13] analysed the composition and physical properties of raw and pasteurised milk Raclette cheeses of good and of insufficient melting quality, and found that the average score indicating good melting quality was below 4.8 for viscosity, consistency and firmness. They concluded that proteolysis "into the width" (SN4.6/TN) led to more viscous and longer texture of melted cheeses, whereas the proteolysis "into the depth" (NPN/TN) led to shorter consistency of melted cheeses.

In this study the average score for viscosity and consistency were below 4.8, and therefore in the required range for good melting quality. Another important sensory parameter is the perception of firmness of the melted cheeses in the mouth during chewing. Figure $8 \mathrm{G}$ shows that all cheeses with score above 4.8 for firmness after 60 days were firm and tough in perception. Figure $8 \mathrm{H}$ shows that after 90 days cheeses became softer and were divisible again into two groups: cheeses made from or with raw milk and those made with pasteurised and microfiltered milk, the latter having a score lower than 4.8. Cheeses made with raw milk were firmer, scoring still above 4.8 thus indicating insufficient melting quality.

To investigate the influence of different milk treatments on melting quality in more detail, further parameters such as softening and dropping point were measured. Figure 9 shows softening and dropping point of Raclette cheeses from different milk treatments regarding the ripening temperature and time. The softening point of all cheeses increased with elevated ripening temperature and time. The dropping point increased also with elevated temperature but not necessarily with longer ripening time.

According to Eberhard et al. [12, 13] the softening point below $58{ }^{\circ} \mathrm{C}$ and the 

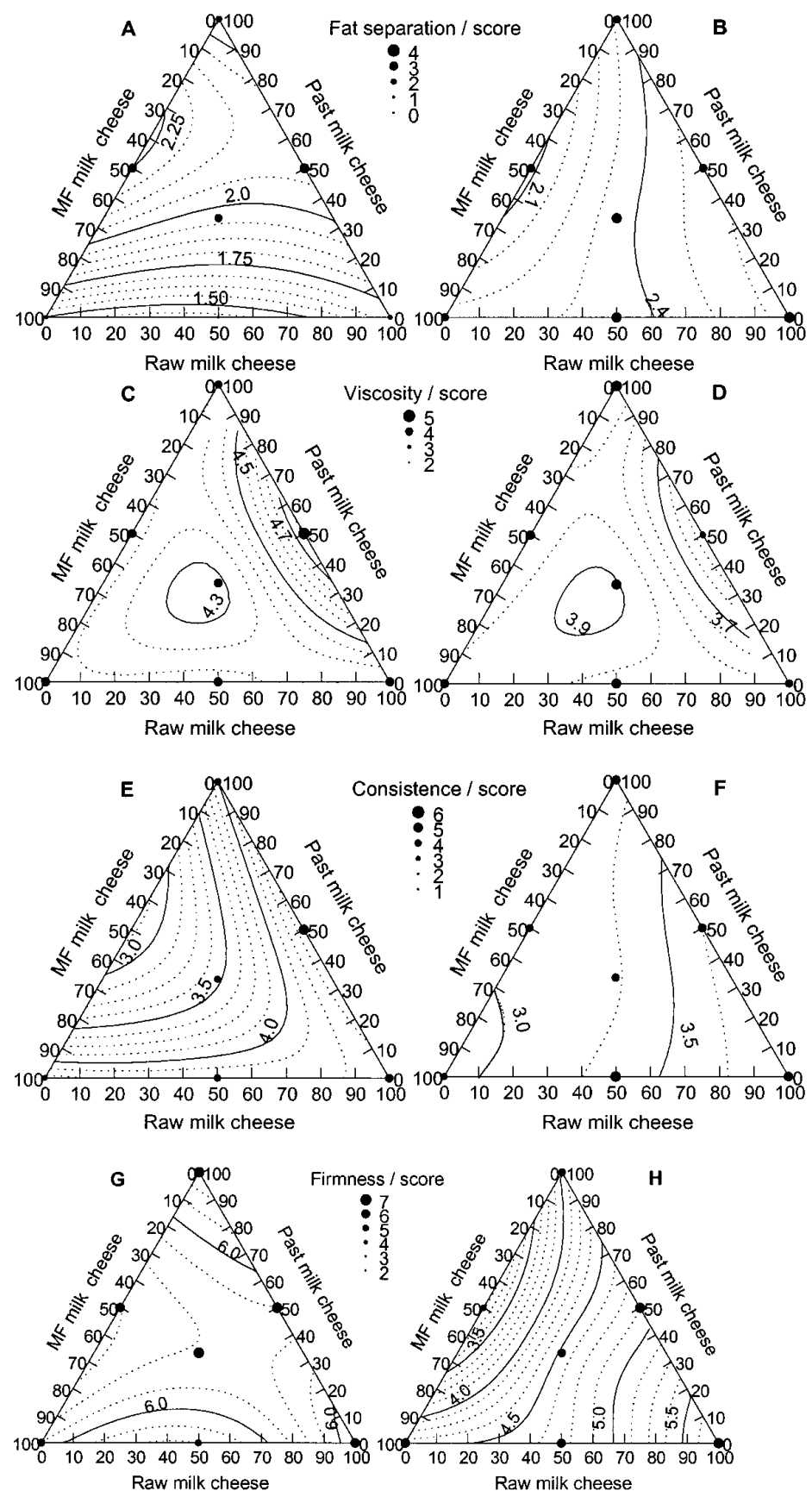

Figure 8. Sensory analysis of melted Raclette cheeses from microfiltered, pasteurised and raw milk. Fat separation after 60 days (A), after 90 days (B), viscosity after 60 days (C) and after 90 days (D), consistence after 60 days (E) and after 90 days (F), firmness after 60 days (G) and after 90 days (H). Means of eight replicates. 
dropping point below $65^{\circ} \mathrm{C}$ are typical for cheeses of good melting quality, which contain more water, more non protein nitrogen and have higher $\mathrm{pH}$, and less fat, calcium and lactic acid compared to cheeses with a poor melting quality. Rüegg et al. [34] found that increased intensity of proteolysis was responsible for lower softening points and therefore better melting properties.

As shown in Figure 9, the influence of ripening temperature at $17{ }^{\circ} \mathrm{C}$ and $20^{\circ} \mathrm{C}$ for 60 and 90 days on softening and dropping point in all cheeses was significant. This can be mainly explained by the fact that at elevated ripening temperatures the moisture content decreased whereas the extent of proteolysis increased. The influence of fat in dry matter and the $\mathrm{NaCl}$ content was negligible. It can be concluded that cheeses of all three milk treatments can be ripened at 11 and $14{ }^{\circ} \mathrm{C}$ for 60 and 90 days without impairment of the softening and dropping point. At $17^{\circ} \mathrm{C}$ for 60 days only MF cheeses showed a dropping point lower than $65^{\circ} \mathrm{C}$ and were in the required range for good melting quality.

\section{CONCLUSION}

The elimination of indigenous raw milk flora by microfiltration leads to significantly reduced concentration of free short chain acids in MF Raclette cheeses which developed less intense flavour compared to raw milk Raclette cheeses. The indigenous raw milk flora in MF cheeses could be reconstructed by addition of a proportion (e.g. one third) of raw milk to MF cheesemilk. Higher ripening temperatures were less
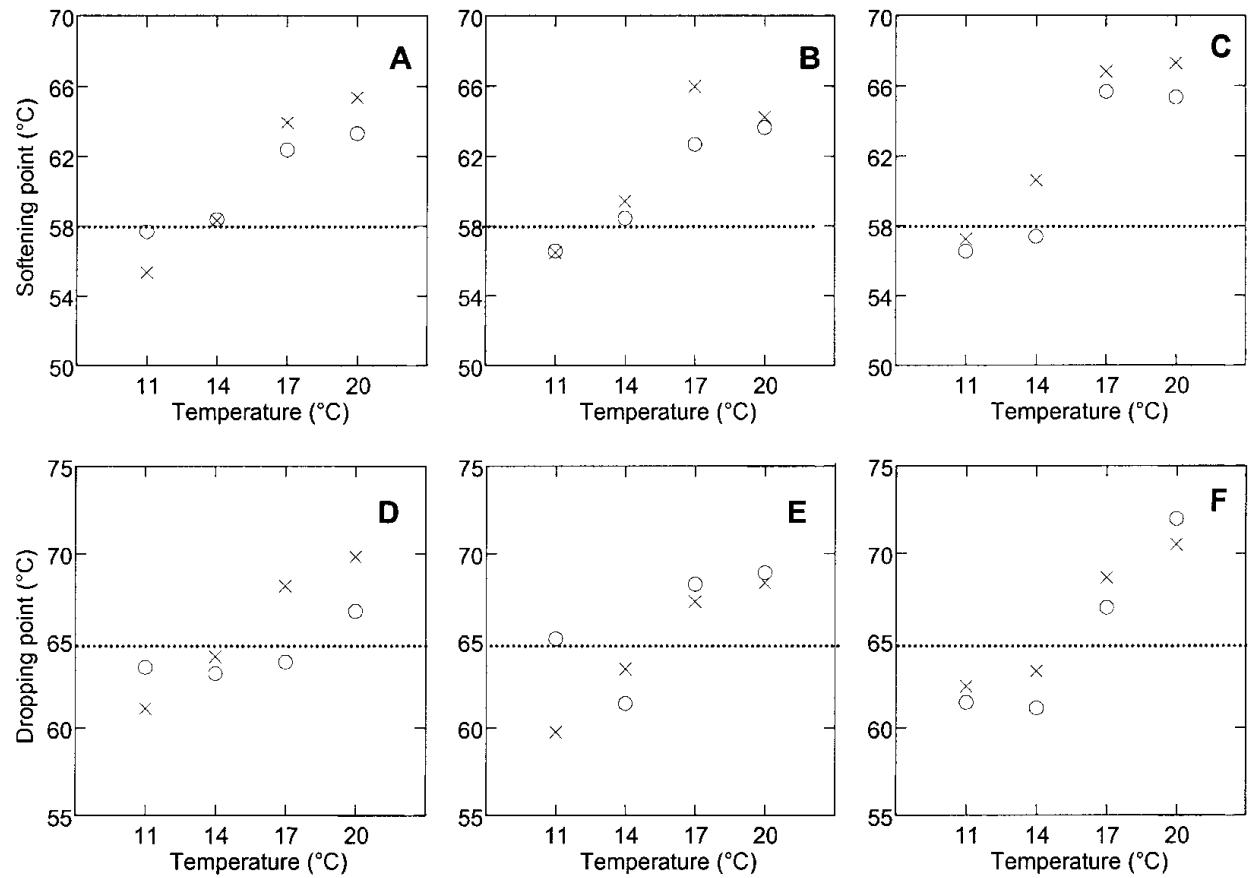

Figure 9. Softening point of Raclette cheeses made from microfiltered milk (A), pasteurised milk (B) and raw milk (C), and dropping point of Raclette cheese made from microfiltered milk (D), pasteurised milk $(\mathbf{E})$ and raw milk $(\mathbf{F})$ after $60(\times)$ and 90 days of ripening $(\bigcirc)$. Upper limit of good melting quality (….). Means of two replicates. 
effective than the addition of raw milk, but were the most promising way to accelerate the ripening of MF cheese. At elevated ripening temperatures above $11^{\circ} \mathrm{C}$ the concentration of free short chain acids and the proteolysis in MF cheeses were enhanced, thus leading to increased intensity of aroma. In order to achieve good sensory and melting quality, MF cheeses could be ripened at $17^{\circ} \mathrm{C}$ for 60 days which is an option for ripening acceleration. In cheeses with raw milk the elevated ripening temperatures caused secondary fermentation as well as flavour defects because of the increased counts of propionibacteria. Cheeses made from pasteurised milk were comparable to those made from MF milk. In Pa and MF cheeses the count of propionibacteria was below the detection limit and at elevated ripening temperatures no secondary fermentation occurred. However, the $\mathrm{Pa}$ Raclette cheese could be ripened only at $\leq 14{ }^{\circ} \mathrm{C}$ for 90 days because the melting quality decreased at higher ripening temperature.

\section{ACKNOWLEDGEMENTS}

We thank the Swiss National Science Foundation for financial support within the framework of the Swiss Priority Programme "Biotechnology" (Grant 5002-044551/1). We also thank U. Bütikofer for his support in the field of statistics.

\section{REFERENCES}

[1] Anonymous, Schweizerisches Lebensmittelbuch, Kapitel 56 "Mikrobiologie", Eidgenossische Drucksachen - und Materialzentrale, Bern (1988) 7.06.

[2] Aston J.W., Fedrick I.A., Durward I.G., Dulley J.R., The effect of elevated ripening temperatures on proteolysis and flavour development in cheddar cheese. I: Higher initial storage temperatures, NZJ Dairy Sci. Technol. 18 (1983) 143-151.

[3] Aston J.W., Grieve P.A., Durward I.G., Dulley J.R., Proteolysis and flavour development in Cheddar cheeses subjected to accelerated ripening treatments, Aust. J. Dairy Technol. 38 (1983) 59-65.
[4] Aston J.W., Giles J.E., Durward I.G., Dulley J.R., The effect of elevated ripening temperatures on proteolysis and flavour development in Cheddar cheese, J. Dairy Res. 52 (1985) 565-572.

[5] Badertscher R., Liniger A., Steiger G., Bestimmung der flüchtigen Fettsäuren in Käse aus dem Wasserdampfdestillat mit « Headspace GD/FID », FAM Information 272 (1993).

[6] Beuvier E., Berthaud K., Cegarra S., Dasen A., Pochet S., Buchin S., Duboz G., Ripening and quality of Swiss-type cheese made from raw, pasteurized or microfiltered milk, Int. Dairy J. 7 (1997) 311-323.

[7] Bouton Y., Grappin R., Comparaison de la qualité de fromages à pâte pressée cuite fabriqués à partir de lait cru ou microfiltré, Lait 75 (1995) 31-44.

[8] Collomb M., Spahni M., Steiger G., Estimation of nitrogen according to Kjeldahl in milk products and some of their nitrogen-containing fractions with an automatic system, Lebensm. Hyg. 81 (1990) 499-509.

[9] Demarigny Y., Beuvier E., Dasen A., Duboz G., Influence of raw milk microflora on the characteristics of Swiss-type cheeses. I. Evolution of microflora during ripening and characterization of facultatively heterofermentative lactobacillin, Lait 76 (1996) 313-416.

[10] Demarigny Y., Beuvier E., Buchin S., Pochet S., Grappin R., Influence of raw milk microflora on the characteristics of Swiss-type cheeses: II. Biochemical and sensory characteristics, Lait 77 (1997) 151-167.

[11] Eberhard P., Moor U., Rüegg M., Flückiger E., Objective Erfassung des Erweichungs- und Tropfpunktes von Raclettekäse, Schweiz. Milchwirt. Forsch. 15 (1986) 93-96.

[12] Eberhard P., Moor U., Rüegg M., Zusammensetzung und physikalische Eigenschaften gut und ungenügend schmelzender Racelttekäse I. Raclettekäse aus pasteurisierter Milch, Schweiz. Milchwirt. Forsch. 17 (1988) 3-8.

[13] Eberhard P., Moor U., Rüegg M., Zusammensetzung und physikalische Eigenschaften gut und ungenügend schmelzender Raclettekäse II. Walliser Raclettekäse, Schweiz. Milchwirt. Forsch. 17 (1988) 47-52

[14] Gallmann P., Einfluss der Rohmilchflora auf die biochemischen Vorgänge der Käsereifung am Beispiel von Raclette-Käse aus pasteurisierter und roher Milch, 85-112. Diss. ETH Nr. 6972, Zürich, 1982.

[15] Gallmann P., Puhan Z., Beeinflussung der Käsequalität durch ausgewählte Mikroorganismen der Rohmilchflora, Schweiz. Milchwirt. Forsch. 11 (1982) 64-69.

[16] Gaya P., Medina M., Rodriguez-Marin M.A., Nunez M., Accelerated ripening of ewes' milk Manchego cheese: the effect of elevated ripening temperatures, J. Dairy Sci. 73 (1990) 26-32. 
17] Glättli H., Dalla Torre M., Zählung von Propionsäurebakterien in Milch, Milchprodukten und Hilfsstoffen, FAM internal report (unpublished), 1995.

[18] Holm S., Malmberg R., Method and plant for producing milk with a low bacterial count, International Patent PCT No WO86/01687, 1986.

[19] IDF, Cheese and processed cheese products. Determination of total solids content, Standard 4A, 1982.

20] IDF, Milk: Determination of nitrogen content (Kjeldahl method) and calculation of crude protein content, Standard 20A, 1986.

[21] IDF, Cheese and processes cheese products. Determination of chloride content. Potentiometric titration method, Standard 88A, 1988.

[22] IDF, Milk and milk products: Preparation of test samples and dilutions, for microbiological examination, Standard 122A, 1988.

[23] ISO, Cheese, Determination of fat content. Van Gulik method, Standard 3433, 1975.

[24] Isolini D., Grand M., Glättli H., Selektivmedien zum Nachweis von obligat und fakultativ heterofermentativen Laktobazillen, Schweiz. Milchwirt. Forsch. 19 (1990) 57-59.

[25] Lidberg E., Bredal B., Suitability of microfiltered cheese milk in the manufacture of Swedish hard cheese, Scand. Dairy Inf. 2 (1991) 20-23.

[26] Malmberg R., Holm S., Producing low-bacteria milk by microfiltration, North Eur. Food Dairy J. 54 (1988) 30-32.

[27] Massart D.L., Vandeginste B.G.M., Buydens L.M.C., De Jong S., Lewi P.J., Smeyers-Verbeke J., Handbook of Chemometrics and Qualimetrics: Part A, Elsevier, Amsterdam (1997) 743-747.

[28] McSweeney P.L.H., Fox P.F., Lucey J.A., Jordan K.N., Cogan T.M., Contribution of the indigenous microflora to the maturation of Cheddar cheese, Int. Dairy J. 3 (1993) 613-634.

[29] Meersohn M., Nitratfreie Bacto, catch-Käseherstellung, North Eur. Food Dairy J. 55 (1989) 108-113.

[30] Mossel D.A.A., Streptokokken der Lancefield Gruppe D in Lebensmittel und Trinkwasser, Arch. Lebensmittelhyg. 29 (1978) 121-127.

[31] Piot M., Vachot J.C., Veaux M., Maubois J.L., Brinkman G.E., Ecrémage et épuration bactérienne du lait entier cru par microfiltration sur membrane en flux tangentiel, Tech. Lait. Market. 1016 (1987) 42-46.

[32] Rosenberg M., Altemueller A.G., Effect of storage temperature on the proteolysis of Cheddar cheese, J. Dairy Sci. (Suppl. 1) 78 (1995) 102.

[33] Roy D., Pitre M., Blanchette L., Savoie L., Bélanger G., Ward P., Maubois J.L., Monitoring proteolysis and cheese juice composition during ripening of Cheddar cheese made from microfiltered milk, Lait 77 (1997) 521-541.

[34] Rüegg M., Moor U., Erweichungs- und Tropfpunktstemperaturen verschiedener Halbhartund Hartkäse, Schweiz. Milchwirt. Forsch. 17 (1988) 69-73.

[35] Schär H., Glättli H., Moor U., Nick B., Sieber R., Steiger G., Untersuchungen über den Reifungsverlauf von qualitativ gutem Walliser Raclettekäse, Schweiz. Milchwirt. Forsch. 21 (1992) 52-57.

[36] Trouvé E., Maubois J.L., Piot M., Madec M.N., Fauquant J., Rouault A., Tabard J., Brinkman G.E., Rétention de différentes espèces microbiennes lors de l'épuration du lait par microfiltration en flux tangentiel, Lait 71 (1991) 1-13.

[37] Vincens D., Tabard J., L'élimination des germes bactériens sur membranes de microfiltration, Tech. Lait. Market. 1033 (1988) 62-64. 